\title{
J-F
}

〔鹿化 第 48 巻, 第 12 号, p. 707 710, 1974]

\section{グラジオラス球根酸性フォスファターゼに 対する陰イオンの影響*}

祐田泰延, 高橋亮司, 岡谷栄三, 山本丈夫

(静岡薬科大学)

昭和 49 年 7 月 3 日受理

Effect of Anions on Acid Phosphatase in Gladiolus Bulbs

(Acid Phosphatase in Plant Part II) [Note]

By Yasunobu SUKETA, Ryoji TAKAHASHI, Eizo OKAYA and Takeo Yamamoto

Shizuoka College of Pharmacy

Effects of various anions on the acid phosphatase in Gladiolus bulbs were studied.

The following results were obtained:

1) The activity of the enzyme was markedly inhibited with fluoride, molybdate or arsenate, respectively.

2) The activity of the enzyme was not influenced with various concentrations of EDTA or EGTA.

3) The inhibition of the enzyme by fluoride was not influenced with addition of phosphate.

(Received July 3, 1974)

前報(1) 飞括いて，グラジオラス球根より $\beta$-グリセ口 リン酸に対して特異性の高い酸性フォスファターゼを約 1300 倍に精媻し，諸性質について調べ報告した。

本報では，先に精製した酔菜標品を用いて，主として 陰イオンに上る醉素活性に与亲る影響について険討し た. 一方, Christian $5^{(2)}$, Malmström ${ }^{(3)}$, Miller $5^{(4)}$ などによって，エノラーゼのフッ素イオン阻害に関する 研究，さらにYang ら ${ }^{(5)}$ にるシュクローズ合成酵素系 でのフッ素イオン阻害に関する研究などが報告されてい る.

そこで，著者らは先に精製した醉菜標品(1)を用いて， フッ素イオンによる阻害についても検討し，2３３の知見 を得た。

実駼材料，醭素調製法：前報(1)飞同じである.

試薬：EDTA 括よびEGTA (=glycol ether diamine

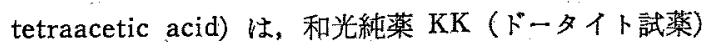

*植物酸性フォスファターゼ（第 2 報）.
を用いた以外はすべて前報(1)飞同じである。

酵素活性測定法：(i) リン酸イオン添加実駼以外の 醭菜活性測定は，すべて前報(1) と同じ測定法によった。 (ii）クロモトロープ酸法に上る酵素活性测定法（リン 酸イオン添加実験の場合）：酸性フォスファターゼ活性 は $\beta$ グリセロリン酸を基質とし，酵素反応により遊離 さるリン酸の代りに，同時に遊離するグリせりンをクロ モトロープ酸法 ${ }^{(6)}$ により定量した。

\section{（I）陰イオンによる影響}

本酵素活性に対するハログンイオンの影響について， 種々イオン濃度について検討し，Fig.1のような結果を 得た. またハャゲン以外の数種の陰イオンの影響につい ても同様，イオン濃度を種々变克て検討し，Fig. 2 のよ らな結果を得た。本酵素は、 、ロダンイオンではフッ素 イオンのみで強く阻害された。 また, ひ酸, 酒石酸扔よ びモリブデン酸イオンによっても強く阻害され，特にモ リブデン酸イオンでは, $10 \mu \mathrm{M}$ の低濃度ではぼ完全に阻 


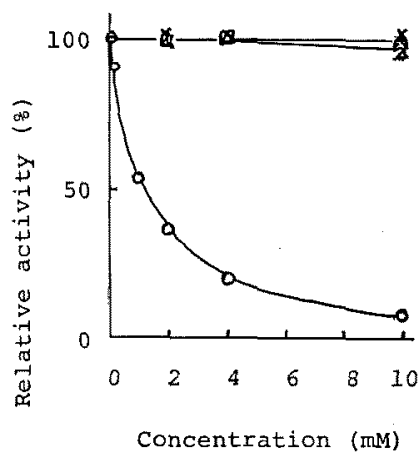

Fig. 1. Effect of Halogen Ions on Acid Phosphatase.

$$
\begin{aligned}
& \mathrm{O}-\mathrm{O} \mathrm{F}^{-}, \quad \times-\times \mathrm{Cl}^{-}, \\
& \triangle-\triangle \mathrm{Br}^{-}, \square-\square \mathrm{I}^{-} .
\end{aligned}
$$

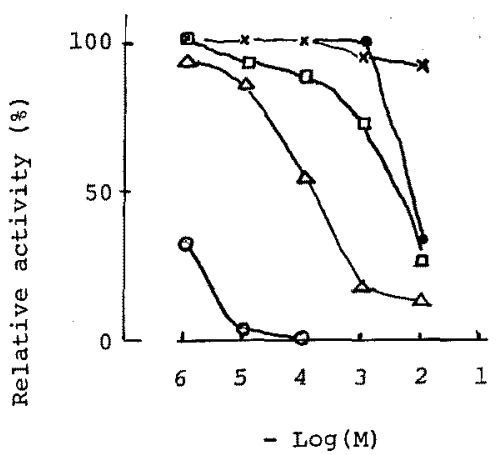

Fig. 2. Effect of Anions on Acid Phosphatase.

$\bigcirc-O$ molybdate, $\Delta-\Delta$ arsenate,

$\square-\square$ taterate, $\times-\times$ sulfate,

The reaction mixture $(2.0 \mathrm{ml})$ containing $0.1 \mathrm{M}$ acetate buffer $(\mathrm{pH} 5.6), 0.61 \mu \mathrm{g}$ of the enzyme protein, $10^{-6} \sim 10^{-2} \mathrm{M}$ various anions and $20 \mu$ moles of substrate was incubated at $37^{\circ} \mathrm{C}$ for $30 \mathrm{~min}$. Activity was expressed as per cert of that without added anions.

青された.このよらなモりブデン酸イオンによる強い阻

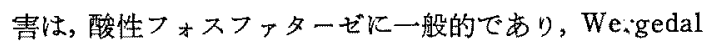
ら(7)の骨の酸性フォスファターゼは, $100 ル \mathrm{M} て ゙ 97 \% の$ 阻害を示したとしている。充たりン酸イオンは，10 $\mathrm{mM}$ で 68\% の阻書を示したが，これは本酵素がリン酸を遊 離することから, product inhibition ですらうと推察さ れる。

なおハロゲンイオンはすべてカリウム塩を，リン酸， ひ酸、酒石酸括よび硫酸イオンは、すべてナトリウム塩

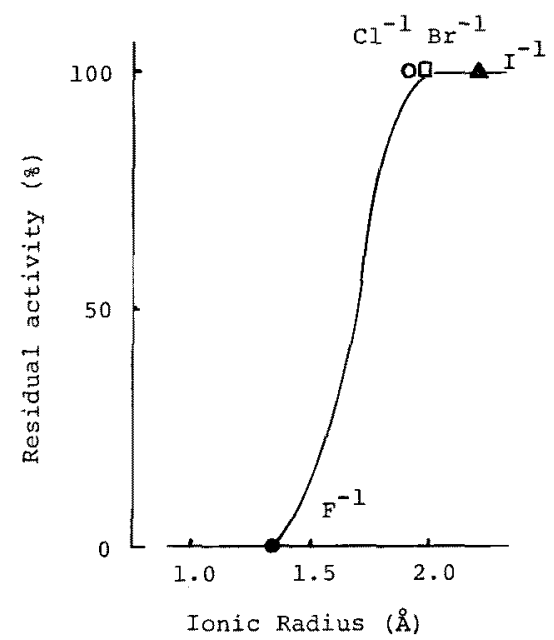

EFig. 3. Relation between Halogen Ionic Radius and Inhibitory Activity.

Concentration of halogen ions : $10^{-2} \mathrm{M}$.
を便用した。

以上の本酵素に対する陰イオンの阻害效果をそれぞれ のイオン半径に従ってプロットしてみると, Fig. 3 战よ び Fig. 4 のごとくになる. ハロゲンではフッ素イオン 以外，イオン半径は約 $2.0 \AA$ 付近で, フッ素イオンの みか゚ $1.3 \AA$ 付近と小さいまた多酷イオンは，それ ぞれ核となるイオンでるって宗したが，Fig. 4 のごと

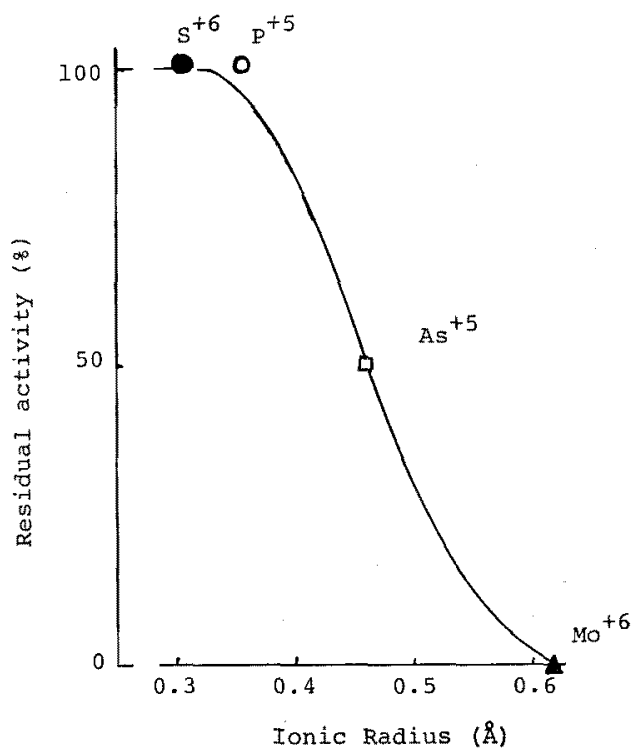

Fig. 4. Relation between Ionic Radius and Inhibitory Activity of Anions.

Concentration of various anions: $10^{-4} \mathrm{M}$. 
く、イオン半径と阻害协果が相関しているといら結果を 得た.

一方，酒石酸は $10^{-2} \mathrm{M}$ で $25 \%$ 程度の阻害を示すが， これは本酵素の活性因子として，金属イオンが関与して いる可能性を推測させた。

\section{（II）金属キレート郕による影響}

本䤉素がフッ素イオン拈よび酒石酸などによって阻書 されることから，金属イオンが本酵素の活性因子として 関与している可能性か゚示唆された。皇こで，EDTA就よ びカルシウムイオンに特異的な EGTA を用いて，本酵 素に与える影響について検討した，その結果，本酵素活 性は EDTA 怙よび EGTA $\left(10^{-6} \sim 10^{-2} \mathrm{M}\right)$ 添加によ。 て，はとえど影響はみられなかった。

(III) フッ素イオンによる阻害

Reiner ら (8)は，300 倍に精製したヒト前立腺酸性フ ォスファターゼを用いてフフッ素イオンによる阻害につ いて検討し，フッ素イオン濃度に上り阻害様式が異なる と報告している，また Tamiya ら 酵母菌）の一種の Fusarium moniliforme から 1360 倍

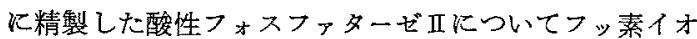
ンによる影響を友ているが，フッ素イオンによる阻害機 構については言及していない。

1) EDTA 存在下でのフッ罢イオン阻害の検討 : 本醭素㴼を，種々濃度の EDTA 存在下でプレインキ ニベートした後，フッ素イオンを添加することにより， 本酵素のフッ素イオン阻害と金属イオンとの関保につい て検討した，その結果，Table I に示すように，本酵素 のフッ素イオン阻害は，EDTA 処理によってほとえと゚

Table I. Reaction of Acid Phosphatase with Fluoride

\begin{tabular}{cccc}
\hline \multicolumn{2}{c}{ Conditions } & & Acid phosphatase \\
EDTA (mM)* & $F^{-}(\mathrm{mM})$ & $\begin{array}{c}\text { Activity } \\
\text { (mmoles/mi/min) }\end{array}$ & $\begin{array}{c}\% \text { of control } \\
\text { activity }\end{array}$ \\
\hline 0 & 0 & 37.2 & 100 \\
0 & 0.25 & 27.9 & 76 \\
0 & 1.25 & 18.2 & 50 \\
1.25 & 0 & 44.4 & $119(100)^{* *}$ \\
1.25 & 0.25 & 30.5 & $82(69)^{* *}$ \\
1.25 & 1.25 & 26.2 & $71(60)^{* *}$ \\
12.5 & 0 & 43.4 & $117(100)^{* *}$ \\
12.5 & 0.25 & 30.3 & $81(69)^{* *}$ \\
12.5 & 1.25 & 26.6 & $72(62)^{* *}$ \\
\hline
\end{tabular}

* The enzyme solution was preincubated with EDTA at $37^{\circ} \mathrm{C}$ for $30 \mathrm{~min}$. ** The number in parentheses shows $\%$ of activity without $\mathrm{F}^{-}$.
Table II. Effect of Phosphate on the Degree of Inhibition of Acid Phosphatase by Fluoride

\begin{tabular}{cccc}
\hline $\begin{array}{c}\text { Phosphate } \\
(\mathrm{mm})\end{array}$ & \multicolumn{2}{c}{ Enzyme activity (\%) } & Inhibition by \\
\cline { 2 - 4 } Without NaF & With NaF & \\
\hline 0 & $100^{\mathrm{a}, \mathrm{b})}$ & $35.3^{\mathrm{a})}$ & 64.7 \\
5 & $54.2^{\mathrm{b})}$ & $19.4^{\mathrm{b})}$ & 64.2 \\
10 & $31.7^{\mathrm{b})}$ & $11.7^{\mathrm{b})}$ & 63.1 \\
15 & $21.0^{\mathrm{b})}$ & $8.2^{\mathrm{b})}$ & 61.0 \\
\hline
\end{tabular}

The reaction mixture $(2.0 \mathrm{ml})$ containing $0.1 \mathrm{M}$ acetate buffer ( $\mathrm{pH} 5.6$ ) $0.61 \mu \mathrm{g}$ of the enzyme protein, $20 \mu$ moles, of substrate, $4 \mu$ moles of fluoride and the amounts indicated phosphate (as $\mathrm{Na}_{2} \mathrm{HPO}_{4}$ ) was incubated at $37^{\circ} \mathrm{C}$ for $30 \mathrm{~min}$.

a) $\mathrm{Pi}$ determination was carried out by the method of Nakamura.(11) b) Glycerine determination was carried out by the method of Korn. (6)

影㽞を受けないことがわかった。

2) フッ素イオン添加時による影響およびフッ秦イオ ン阻害の可逆性： 本醉素のフッ素イオン阻害の Lineweaver-Burk プロットは，前報(1)のごとく直線性を示 さなかったててこでファッ素イオンの潘加時の影響につ いて，基質濃度の高い場合 $(10 \mathrm{mM})$ と低い場合 (1 mM) についてそれぞれ検討したが，フッ謤イオン添加時によ る影留㤌，いずれの場合にも任とえどみられなかった。

また本酔素のフッ素イオン阻害の可逆性については， 本醭素溶液をフッ素イオン存在下で $37^{\circ} \mathrm{C}, 20$ 分間イン キュペートした後， $4^{\circ} \mathrm{C} て ゙ 0.1 \mathrm{M}$ 酶酸緩衝液に対して透 析し，経時的に活性の回復を追ってみたところ，24 時 間透析で酳素活性は注注全に回復した。この結果，フ 素イオンによる本酳素の阻害は可逆的であることがわ かった.

3）フッ素イオン阻害に与えるリン酸イオンの影響 : Slater ら (10)は，コハク酸酸化酵素がフッ素イオンで阻 害されるが，さらにリン酸イオンを共存させることによ り，フッ素イオンによる阻害が增強されることを竍告し ている.

そこでこの点についても検討した，その結果は Table II のごとくで，本䤃素のフッ素イオン阻害度は， リン酸イオン濃度を增すことにより增強されるとはいい がたい。

（1）祐田泰延，岡谷栄三，高橋亮司，山本丈夫：農 化, 48, 537 (1974).

(2) C. Warburg and W. Christian : Biochem. Z., 310, 385 (1942).

(3) B. G. Malmström : Arch. Biochem. Biophys., 
46, 345 (1953).

(4) G. W. Miller : Plant Physiol., 32, 199 (1957).

(5) S. F. Yang and G. W. Miller : Biochem. J., 88, 509 (1963).

(6) E. D. Korn: Methods Biochem. Anal., 7, 145 (1959).

(7) J.E. Wergedal : Proc. Soc. Exp. Med. Med., 134, 244 (1970).
(8) J. M. Reiner, K. K. Tsuboi and P.B. Hudson: Arch. Biochem. Biophys., 56, 165 (1955).

(9) H. Yoshida and N. Tamiya : J. Biochem., 69, 525 (1971).

(10) E. C. Slater and W. D. Bonner: Biochem. J., 52, 185 (1952).

（11）中村道德：農化，24，1 (1950). 